Doi: HTTPS://DOI.ORG/10.23910/IJBSM/2017.8.2.1685

\title{
Evaluation of Some Insecticides Against Brown Plant Hopper, Nilaparvata lugens (Stal) in Rice, Oryza sativa L.
}

\author{
Atanu Seni* and Bhima Sen Naik
}

Orissa University of Agriculture and Technology-Chiplima Campus, RRTTS, Chiplima, Sambalpur, Odisha (768 025), India

Corresponding Author

Atanu Seni

e-mail: atanupau@gmail.com

\author{
Article History \\ Manuscript No. AR1685 \\ Received in $12^{\text {th }}$ September, 2016 \\ Received in revised form $27^{\text {th }}$ January, 2017 \\ Accepted in final form $26^{\text {th }}$ March, 2017
}

\begin{abstract}
A field experiment was conducted to determine the comparative efficacy of some newer insecticides with some conventional insecticides against brown plant hoppers (BPH) in rice during kharif 2014 and rabi, 2014-2015. The treatments include: Thiamethoxam 25 WG @ 37.50 g a.i. ha- ${ }^{-1}$, Lamda cyhalothrin 5 EC @ 30 g a.i. ha ${ }^{-1}$, Pymetrozine 50 WG @ 150 g a.i. ha ${ }^{-1}$, Buprofezin 25 SC @ 250 g a.i. ha-1 ${ }^{-1}$ Glamore (Imidachloprid 40+Ethiprole 40\% w/w) 80 WG @ 100 g a.i. ha ${ }^{-1}$, Dinotefuran 20 SG @ 40 g a.i. ha ${ }^{-1}$, Acephate 75 SP @ 564 g a.i. ha-1 ${ }^{-1}$ untreated control and a basal application of fipronil $0.3 \mathrm{G} @ 25 \mathrm{~kg} \mathrm{ha}^{-1}$ was made once at 25 DAT in all treatments except untreated control. All the treatments were effective for hoppers management than control. The overall data revealed that the Pymetrozine 50 WG @ $150 \mathrm{~g}$ a.i. ha ${ }^{-1}$ recorded significantly higher percent reduction of hoppers and higher grain yield than the other treatments. Pymetrozine 50 WG @ $150 \mathrm{~g}$ a.i. ha ${ }^{-1}$ treated plot also had more number of spiders (3.71 spiders 10 hills $^{-1}$ after 10 DAT of last spray) than other chemical treated plots. In cost benefit ratio it is observed that the Pymetrozine 50 WG @ $150 \mathrm{~g}$ a.i. ha ${ }^{-1}$ (1:4.18) and Lamda cyhalothrin 5 EC @ 30 g a.i., ha ${ }^{-1}$ (1:4.46) treated plots had more return than expenditure.
\end{abstract}

Keywords: $\mathrm{BPH}$, cost benefit ratio, insecticides, rice, yield

\section{Introduction}

Rice (Oryza sativa L.) is one of the world's most important crops providing a staple food for more than half of the global population (Kulagod, 2011). It is the predominant dietary energy source for 17 countries in Asia and the Pacific, 9 countries in North and South America and 8 countries in Africa. It alone provides $20 \%$ of the world's dietary energy supply (FAO, 2004). But, rice production is hampers by infestation of a large number of insect pests. Nearly 300 species of insect pests attack the rice crop at different stages and among them only 23 species cause notable damage (Pasalu and Katti, 2006). Brown plant hopper is one of the major culprits for huge economic crop losses of rice. It attacks the crop from late vegetative stage to grains hardening stage. Both the nymphs and adults of this insect suck the sap from the plant resulting in chlorotic, wilting and drying up of rice plant. This feeding damage is commonly known as 'hopper-burn' which begins in patches but spread rapidly as the hoppers move from dying plants to adjacent plants. Generally the yield losses due to hoppers ranges from $10 \%$ to $90 \%$ but if timely control measures are not taken up, there may be possibility of total crop loss within a very short period. Beside this direct feeding damage, it also serves as the vector of Rice Grassy Stunt and
Ragged Stunt Viruses (Ling, 1977). Farmers rely heavily on insecticides for their management and almost 50\% of the insecticides used in rice are targeted against this pest alone (Reddy et al., 2012). Many conventional insecticides though have been evaluated against this insect, yet, most of the chemicals have failed to provide adequate control. Hence, new molecules are being added for their evaluation with an aim to least disruption of environmental quality. For this, the present study was carried out to find the efficacy of certain new molecules against Brown plant hoppers in rice.

\section{Materials and Methods}

The experiment was conducted in the experimental farm of Regional Research and Technology Transfer Station (OUAT), Chiplima, Sambalpur, Odisha, during kharif, 2014 and rabi, 2014-15 in Randomized Block Design (RBD), having 8 treatments which were replicated thrice in a net experimental area of $5 \times 4 \mathrm{~m}^{2}$ each. The Station is situated at $20^{\circ} 21^{\prime} \mathrm{N}$ latitude and $80^{\circ} 55^{\prime} \mathrm{E}$ longitude in Dhankauda block of Sambalpur district at an altitude of $178.8 \mathrm{MSL}$. The climate of the area is warming sub-humid. The temperature varies from as low as $9^{\circ} \mathrm{C}$ to as high as $44.2^{\circ} \mathrm{C}$. The mean maximum and the mean minimum temperatures of $40.5^{\circ} \mathrm{C}$ and $13^{\circ} \mathrm{C}$ are recorded in 
the months of May and December, respectively. Nursery of rice variety Jaya sown in the middle week of July in kharif, 2014 and last week of December in rabi, 2014-15 and transplanting was done after 25 days of sowing at $20 \times 15 \mathrm{~cm}^{2}$ hill spacing. All the agronomic practices were followed during crop growth period. The treatments were: T1-Thiamethoxam 25 WG @ $37.50 \mathrm{~g}$ a.i. ha ${ }^{-1} ; \mathrm{T}_{2}$-Lamda cyhalothrin 5 EC @ $30 \mathrm{~g}$ a.i. ha ${ }^{-1}$; $\mathrm{T}_{3}$-Pymetrozine 50 WG @ $150 \mathrm{~g}$ a.i. ha- ${ }^{-1} ; \mathrm{T}_{4}$-Buprofezin 25 SC @ $250 \mathrm{~g}$ a.i. ha-1; $\mathrm{T}_{5}$-Glamore (Imidachloprid 40+Ethiprole 40\% w/w) 80 WG @ 100 g a.i. ha ${ }^{-1} ; T_{6}$-Dinotefuran 20 SG @ 40 g a.i. ha-1; $\mathrm{T}_{7}$-Acephate 75 SP @ 564 g a.i. ha- ${ }^{-1} ; \mathrm{T}_{8}$-untreated control. Beside these, a basal application of fipronil $0.3 \mathrm{G} @$ $25 \mathrm{~kg} \mathrm{ha}^{-1}$ was made once at 25 DAT in all treatments except untreated control. Applications of other treatments were done at 55 DAT and 65 DAT. The insecticides were applied as high volume sprays @ 500 lits of spray fluid/ha. The hopper population hill-1 was recorded before spray and 7 days after each spray and percent reduction over control of hoppers was calculated. The spider (natural enemies) population hill${ }^{1}$ was recorded 1 day before and after 10 days of last spray. The data thus obtained from field experiments were analyzed statistically by ANOVA. Finally the grain yield was recorded in plot basis and expressed in quintal ha-1 ${ }^{-1}$ Based on yield, cost benefit ratios of different treatments were also calculated.

\section{Results and Discussion}

\subsection{Hoppers management}

From the Table 1 and 2, it is revealed that among different treatments, $\mathrm{T}_{3}$ : Pymetrozine 50 WG @ $150 \mathrm{~g}$ a.i. ha ${ }^{-1}$ was recorded to be significantly superior (>70\% reduction over

Table 1: Efficacy of insecticides against plant hoppers in kharif, 2014

\begin{tabular}{|c|c|c|c|c|}
\hline \multirow[t]{2}{*}{ Treatments } & \multirow{2}{*}{$\begin{array}{l}\text { Dose } \\
(\mathrm{g} \text { a.i. } \\
\left.\mathrm{ha}^{-1}\right)\end{array}$} & \multicolumn{2}{|c|}{$\begin{array}{l}\text { No. hoppers } \\
10 \text { hill-1 }^{-1}\end{array}$} & \multirow{2}{*}{$\begin{array}{l}\text { \% reduc- } \\
\text { tion over } \\
\text { control }\end{array}$} \\
\hline & & PTC & 7 DAT & \\
\hline $\begin{array}{l}\mathrm{T}_{1}: \text { Thiamethoxam } \\
25 \mathrm{WG}\end{array}$ & 37.50 & 90.00 & 43.00 & 57 \\
\hline $\begin{array}{l}\mathrm{T}_{2}: \text { Lamda cyhalothrin } \\
5 \mathrm{EC}\end{array}$ & 30.00 & 89.33 & 33.33 & 67 \\
\hline $\begin{array}{l}\mathrm{T}_{3}: \text { Pymetrozine } 50 \\
\text { WG }\end{array}$ & 150.00 & 88.67 & 24.33 & 76 \\
\hline $\mathrm{T}_{4}$ : Buprofezin $25 \mathrm{SC}$ & 250.00 & 85.33 & 43.67 & 56 \\
\hline $\mathrm{T}_{5}:$ Glamore $80 \mathrm{WG}$ & 100.00 & 84.33 & 35.33 & 65 \\
\hline $\begin{array}{l}\mathrm{T}_{6}: \text { Dinotefuran } 20 \\
\text { SG }\end{array}$ & 40.00 & 86.33 & 45.33 & 55 \\
\hline $\mathrm{T}_{7}:$ Acephate $75 \mathrm{SP}$ & 564.00 & 84.33 & 49.67 & 50 \\
\hline $\mathrm{T}_{8}:$ Untreated control & - & 87.00 & 99.67 & - \\
\hline SEm \pm & & & 1.66 & \\
\hline $\operatorname{CD}(p=0.05)$ & & NS & 5.03 & \\
\hline
\end{tabular}

Table 2: Efficacy of insecticides against plant hoppers in rabi, 2014-15

\begin{tabular}{lcccc}
\hline \multirow{2}{*}{$\begin{array}{l}\text { Treat- } \\
\text { ments }\end{array}$} & $\left.\begin{array}{c}\text { Dose } \\
(\text { a.i. ha }\end{array}{ }^{-1}\right)$ & \multicolumn{2}{c}{ No. hoppers 10 hill $^{-1}$} & \multirow{2}{*}{$\begin{array}{c}\text { \% reduction } \\
\text { over control }\end{array}$} \\
$\mathrm{T}_{1}$ & 37.50 & 102.00 & 48.67 & 62 \\
$\mathrm{~T}_{2}$ & 30.00 & 103.67 & 37.67 & 71 \\
$\mathrm{~T}_{3}$ & 150.00 & 104.67 & 29.33 & 77 \\
$\mathrm{~T}_{4}$ & 250.00 & 100.00 & 50.00 & 61 \\
$\mathrm{~T}_{5}$ & 100.00 & 107.00 & 38.00 & 70 \\
$\mathrm{~T}_{6}$ & 40.00 & 103.33 & 52.33 & 59 \\
$\mathrm{~T}_{7}$ & 564.00 & 108.67 & 54.00 & 58 \\
$\mathrm{~T}_{8}$ & - & 104.33 & 128.00 & - \\
$\mathrm{SEm} \pm$ & & & 2.34 & \\
$\mathrm{CD}(p=0.05)$ & & $\mathrm{NS}$ & 7.10 & \\
\hline
\end{tabular}

Note: Data were analyzed without transformation as there was significant difference among the treatment without zero value.

control) in efficacy against plant hoppers in both seasons, as it is recorded highest mean percent reduction of hoppers over control. $T_{2}$ and $T_{5}$ Treatments were at par with each other in hopper management. All The treatments were superior in hopper management and differed significantly from untreated control plot. De-Jin, 2010 observed the effectiveness of Pymetrozine for BPH management. Different scientists were also reported the effectiveness of Buprofezin and Thiamethoxam for hopper management (Kendappa et al., 2005; Hegde and Nidagundi, 2009; Suri et al., 2012). Kirankumar, 2016 studied the efficacy of Pymetrozine 50 WG against brown plant hopper of rice and found it is quite effective for $N$. lugens management and pymetrozine treated plots gave higher yield with least effect on natural enemies. (Naik et al., 2016) also mentioned the effectiveness of Pymetrozine 50 WG @ $0.6 \mathrm{~g} \mathrm{l}^{-1}$ and Glamore (Imidachloprid+Ethiprole) @ $0.25 \mathrm{~g} \mathrm{l}^{-1}$ of water for hoppers management.

\subsection{Effect on spider}

Spiders are one of the important predators of rice planthoppers and leafhoppers. Due to the indiscriminate and nonselective use of insecticides causes disruption of their life cycle. For this, selection of insecticides is very important for conserve them. From the Table 3, it is found that maximum spider population was present in control plot (6.70 spiders 10 hills $^{-1}$ after 10 DAT of last spray) followed by Pymetrozine 50 WG @ 150 g a.i. ha- $^{-1}$, Buprofezin 25 SC @ 250 g a.i. ha ${ }^{-1}$, Lamda cyhalothrin 5 EC@ 30 g a.i. ha- ${ }^{-1}$, Dinotefuran 20 SG @ 40 g a.i. ha ${ }^{-1}$, Glamore 80 WG @ 100 g a.i. ha-1, Thiamethoxam 25 WG @ 37.50 g a.i. ha-1 and Acephate 75 SP @ 564 g a.i. ha- ${ }^{-1}$ treated plots. $T_{1}, T_{2}$, $T_{5}$ and $T_{6}$ treatments were at par with each other in spider numbers 10 hills $^{-1}$ after 10 DAT of last spray. It is observed that lower spider population found in Acephate 75 SP @ 564 
Table 3: Effect of chemicals on spider population after 10 DAT of last spray

\begin{tabular}{lccc}
\hline Treatments & $\begin{array}{c}\text { Dose } \\
\text { (g a.i. ha }\end{array}{ }^{-1}$ ) & \multicolumn{2}{c}{ Spider 10 hill $^{-1}$} \\
\cline { 3 - 4 } & 37.50 & Before spray & After spray \\
\hline $\mathrm{T}_{1}$ & 30.00 & 2.30 & 1.70 \\
$\mathrm{~T}_{2}$ & 150.00 & 2.70 & 2.30 \\
$\mathrm{~T}_{3}$ & 250.00 & 2.30 & 3.71 \\
$\mathrm{~T}_{4}$ & 100.00 & 3.00 & 3.03 \\
$\mathrm{~T}_{5}$ & 40.00 & 2.30 & 2.70 \\
$\mathrm{~T}_{6}$ & 564.00 & 3.00 & 1.30 \\
$\mathrm{~T}_{7}$ & - & 6.00 & 6.70 \\
$\mathrm{~T}_{8}$ & & 0.42 & 0.31 \\
$\mathrm{SEm} \pm$ & & 1.26 & 0.93 \\
$\mathrm{CD}(p=0.05)$ & & & \\
\hline
\end{tabular}

$\mathrm{g}$ a.i. ha ${ }^{-1}$ treated plot in both season. Our observation was in accordance with the (De-Jin et al., 2010) findings where they had observed that the impact of Pymetrozine on spiders was insignificant after spray and was safe to spiders.

\subsection{Yield}

It is found that in Table 4, T Pymetrozine 50 WG @ 150 g a.i. ha-1 treated plot recorded highest yield of 48.09 Qt ha $^{-1}$ followed by Glamore 80 WG, Lamda cyhalothrin 5 EC, Dinotefuran 20 SG, Thiamethoxam 25 WG, Buprofezin 25 SC, Acephate 75 SP treated plots. All The treatments given plots gave superior yield than untreated control plot.

\begin{tabular}{lcccc}
\hline Table 4: Effect of certain chemicals on grain yield of rice \\
\hline Treatments & \multicolumn{2}{c}{$\begin{array}{c}\text { Grain yield } \\
\text { (q ha- } \text { h }^{-1}\end{array}$} & Mean & $\begin{array}{c}\text { (\%) yield in- } \\
\text { crease over } \\
\text { control }\end{array}$ \\
\cline { 2 - 3 } & $\begin{array}{c}\text { Kharif, } \\
2014\end{array}$ & $\begin{array}{c}\text { Rabi, } \\
\text { 2014-15 }\end{array}$ & & \\
\hline $\mathrm{T}_{1}$ & 37.40 & 38.53 & 37.97 & 31.06 \\
$\mathrm{~T}_{2}$ & 39.10 & 39.60 & 39.35 & 33.48 \\
$\mathrm{~T}_{3}$ & 47.37 & 48.80 & 48.09 & 45.56 \\
$\mathrm{~T}_{4}$ & 36.73 & 37.37 & 37.05 & 29.36 \\
$\mathrm{~T}_{5}$ & 40.57 & 41.83 & 41.20 & 36.47 \\
$\mathrm{~T}_{6}$ & 37.93 & 39.83 & 38.88 & 32.68 \\
$\mathrm{~T}_{7}$ & 35.37 & 36.97 & 36.17 & 27.63 \\
$\mathrm{~T}_{8}$ & 25.50 & 26.85 & 26.17 & - \\
$\mathrm{SEm} \pm$ & 0.23 & 0.31 & & \\
$\mathrm{CD}(p=0.05)$ & 0.69 & 0.93 & & \\
\hline
\end{tabular}

\subsection{Cost benefit ratio}

From the Table 5 , it is found that maximum cost benefit ratio was recorded in Pymetrozine 50 WG @ 150 g a.i. ha ${ }^{-1}$ (1: 4.18) and Lamda cyhalothrin 5 EC @ 30 g a.i. ha ${ }^{-1}$ (1: 4.46) treated plots. Among other treatments, Thiamethoxam 25 WG, Glamore 80 WG and Acephate 75 SP treated plots had good cost benefit ratio. Among the different tested insecticides, spraying of conventional organophosphate insecticides, Acephate still have good cost benefit ratio. Previously, many scientists also documented the good efficacy of Acephate against hoppers (Bhavani and Rao, 2005; Fabellar and Heinrichs, 2003; Reddy et al., 2012).

Table 5: Effect of certain chemicals on cost benefit ratio for $\mathrm{BPH}$ management

\begin{tabular}{lcccccc}
\hline $\begin{array}{l}\text { T. } \\
\text { No. }\end{array}$ & $\begin{array}{c}\text { Dose } \\
\left(\mathrm{ml} \mathrm{ha}^{-1}\right)\end{array}$ & IC & $\begin{array}{c}\text { RY } \\
\left(\mathrm{q} \mathrm{ha}^{-1}\right)\end{array}$ & $\begin{array}{c}\text { EY- } \\
\text { OUC }\end{array}$ & VAY (₹) & $\begin{array}{c}\text { B:C } \\
\text { ratio }\end{array}$ \\
\hline $\mathrm{T}_{1}$ & 37.50 & 4350 & 37.97 & 11.80 & 17105.17 & $1: 3.93$ \\
$\mathrm{~T}_{2}$ & 30.00 & 4288 & 39.35 & 13.18 & 19111.00 & $1: 4.46$ \\
$\mathrm{~T}_{3}$ & 150.00 & 7602 & 48.09 & 21.92 & 31784.00 & $1: 4.18$ \\
$\mathrm{~T}_{4}$ & 250.00 & 5350 & 37.05 & 10.88 & 15776.00 & $1: 2.95$ \\
$\mathrm{~T}_{5}$ & 100.00 & 5580 & 41.20 & 15.03 & 21793.50 & $1: 3.91$ \\
$\mathrm{~T}_{6}$ & 40.00 & 6010 & 38.88 & 12.71 & 18434.33 & $1: 3.07$ \\
$\mathrm{~T}_{7}$ & 564.00 & 3870 & 36.17 & 10.00 & 14500.00 & $1: 3.75$ \\
$\mathrm{~T}_{8}$ & - & - & 26.17 & - & - & - \\
\hline
\end{tabular}

RY: Rice yield; IC: Input cost (Insecticide including fipronil and labour cost ha ${ }^{-1}$ ); EYOUC: Extra yield over untreated control; VAY: Value of additional yield

\section{Conclusion}

All the tested chemicals are effective for hopper management but among the newer insecticide molecules Pymetrozine 50 WG @ 150 g a.i. ha ${ }^{-1}$ and Glamore 80 WG @ 100 g a.i. ha ${ }^{-1}$ can be used for the effective management of brown plant hopper in both kharif and rabi seasons in rice.

\section{Acknowledgement}

The authors are highly thankful to ICAR-Indian Institute of Rice Research, Rajendranagar, Hyderabad and Orissa University of Agriculture and Technology, Bhubaneswar for financial assistance.

\section{References}

Bhavani, B., Rao, P.R.M., 2005. Bio-efficacy of certain insecticides against rice plant hoppers vis- $a$-vis Natural enemies under irrigated field condition. Indian Journal of Plant Protection 33(1), 64-67.

De-Jin, X.U., Zhong-Yan, G.U., Guang-Chun, X.U., XiaoLong, X.U., Peng, F., 2010. Pymetrozine application techniques against Nilaparvata lugens (Stål) and safety evaluation to its natural enemies. Chinese Journal of Eco-Agriculture, http://en.cnki.com.cn/Article_en/ CJFDTOTAL-ZGTN201005028.htm.

Fabellar, L.T., Heinrichs, E.A., 2003. Relative toxicity of insecticides to rice plant hoppers and their predators. 
Crop Protection 5(4), 254-258.

Food and Agricultural Organization of the United Nations, 2004. The state of food security in the world, FAO, Rome, Italy, 30-31.

Hegde, M., Nidagundi, J., 2009. Effect of newer chemicals on planthoppers and their mirid predator in rice. Karnataka Journal of Agricultural Sciences 22, 511-513.

Kendappa, G.N., Mallikarjunappa, S., Shankar, G., Mithyantha, M.S., 2005. Evaluation of new insecticide, Applaud 25 SC (buprofezin) against brown planthopper, Nilaparvata lugens (Stal.) (Family:Delphacidae, Order:Hemiptera). Pestology 29, 5-8.

Kirankumar, R., 2016. Efficacy of Pymetrozine 50 WG against brown planthopper Nilaparvata lugens (Stal) on paddy Oryza sativa L. International Journal of Plant Protection 9(1), 68-78.

Kulagod, S.D., Hegde, M., Nayak, G.V., Vastrad, A.S., Hugar, P.S., Basavanagoud, K., 2011. Evaluation of insecticides and bio-rationals against yellow stem borer and leaf folder on rice crop. Karnataka Journal of Agricultural Sciences 24(2), 244-246.

Ling, K.C., 1977. Rice ragged stunt disease. International Rice Research Newsletter 5, 6-7.

Naik, B.S., Swain, D., Pal, R., Seni, A., Nayak, B.R., 2016. Progress of rice research in the west central table land zone of Odisha in India. International Journal of Advanced Research 4(5), 795-802.

Pasalu, I.C., Katti, G., 2006. Advances in ecofriendly approaches in rice IPM. Journal of Rice Research 1(1), 83-90.

Reddy, A.V., Devi, R.S., Reddy, D.V.V., 2012. Evaluation of botanical and other extracts against plant hoppers in rice. Journal of Bio-pesticides 5(1), 57-61.

Suri, K.S., Kumar, V., Brar, D.S., 2012. Field evaluation of insecticides for the management of rice plant hoppers, Sogatella furcifera and Nilaparvata lugens. Indian Journal of Plant Protection 40(2), 153-156. 